\title{
Endemic time-spaces of Finland: Aquatic regimes
}

\author{
TERO MUSTONEN
}

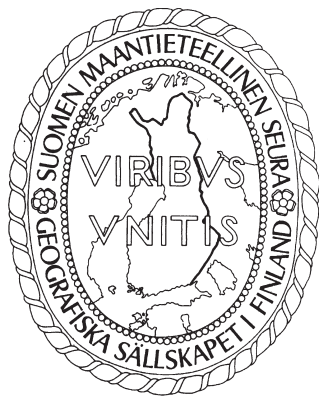

Mustonen, Tero (2014). Endemic time-spaces of Finland: Aquatic regimes. Fennia 192: 2, pp. 120-139. ISSN 1798-5617.

\begin{abstract}
This article explores the endemic time-spaces of Finnish aquatic regimes. More precisely, it examines the socio-ecological relationships between Finns and lakes, rivers, and marshes-mires. First, the 'engine' of endemic time-space research, land use, and occupancy documentation, is explored in the Finnish context. Then two catchment areas, Kokemäenjoki in Western Finland and Vuoksi in Eastern Finland, provide cases which illustrate both past endemic time-spaces and surviving aspects of cultural readings of lakes and rivers. The ongoing winter seining in Lake Puruvesi in North Karelia emerges as an unbroken practice, with deep roots, that maintains the endemic time-spaces of a traditional Finnish relationship with a lake. As industrial uses of catchment areas, zoning, and environmental permitting exclude endemic readings inherent on the land and waterscapes, solutions are explored through mapping, along with its limitations, as a form bridging the gap between local realities and resource extraction.
\end{abstract}

Keywords: Kokemäenjoki, time-space, oral history, Vuoksi, winter seining, Finnish tradition

Tero Mustonen, The Department of Geographical and Historical Studies, University of Eastern Finland, P. O. Box 111, 80101 Joensuu, Finland, E-mail: tero@ snowchange.org

\section{Introduction}

"My father told me that the people of Hiisi [one of the old Finnish spirit-gods] travelled on the Lake Kuivasjärvi in winter time. I do not remember the kind of noise they made, but old people said that they are there, moving." From a conversation with a 92-year-old subsistence fisherman, Kuivasjärvi, Snowchange Kuivasjärvi Oral History Tape 120214

"Endemic" refers to the internal, place-bound, and culturally-specific (Sheridan \& Longboat 2006; Meriläinen-Hyvärinen 2008: 36) in human societies. Meriläinen-Hyvärinen (2008: 36) defines the components of a nature-based endemicity to consist of a community, a cultural core, and the continuation of a livelihood. Concentric geographs (Lehtinen 2011) are another way to frame the particularity of this place- and culture-based approach. Also central to the concept of endemicity is local, sometimes traditional, knowledge
(Berkes 1999; Luotonen 2006; Sheridan \& Longboat 2006; Heikkilä \& Fondahl 2010; Lehtinen \& Mustonen 2013).

Time and space as well as their interpretations are much explored topics in human geography (Thrift \& May 2001: 5). To address the spatial turn in theory, Thrift and May (2001: 5) define the concept of timespace, or time-space, as a "spatial variation a constitutive part rather than added dimension of the multiplicity and heterogeneity of social time". They stress (2001: 5) that time-space is the product of dynamic and unequal inter-relationalities. They stress the need to 'live' or explore 'lived' time-spaces in their heterogeneity.

Endemic time-space is therefore a range of spatial-temporal practices of a specific culture, group or ethnic unit. Linda Tuhiwai Smith (2005: 50), a Maori from Aotearoa (New Zealand), explicitly states in reference to the time-space apparatus that: "These concepts are particularly significant for some indigenous languages because the lan- 
guage makes no clear or absolute distinction between the two: for example, the Maori word for time or space is the same. Other indigenous languages have no related word for either space or time, having instead a series of very precise terms for parts of these ideas or for relationships between the idea and something else in the environment."

The endemic time-spaces of Finns have remained in a hidden realm (Lehtinen 2000). In order to shed light on this topic, this article reviews three cases while tracing and illustrating the surviving characteristics of these relationships. Aside from the Sámi regions, the spatial ordering that Finns have regarding aquatic ecosystems, the sea, lakes, rivers, marsh-mires (Lehtinen 2000), and other water bodies, has developed to contain almost historically diametrically opposing views in contemporary times. Typically across the country, general knowledge production (Mustonen 2009) such as schooling, Western religions, the enforcement of capitalistic-intensive resource economies, and mass media, have eroded the local ecological knowledge (Luotonen 2006) and endemic time-spaces built on local traditions.

As Lehtinen (2000) and Maaranen (2002) explore in the case of marsh-mires, this crux can be summarised into, firstly, utilitarian uses and agrarian landscapes derived from agricultural needs (for example, flood control, water regulation, additional farm land) (Maaranen 2002: 104, Mustonen 2013a) and secondly, a varied fisheries-hunting approach (Sarmela 1991) which include(d) various endemic time- or 'mirescapes' (Lehtinen 2000), for example. The latter is predominantly concerned with the ongoing productivity and health of water-bodies as stable, near to natural units with cultural continuums (Lehtinen 2000). Such a division is naturally an abstraction; local cases can be hybrids and exceptions to this summarization (Maaranen 2002: 104).

The crux is not only an academic view, as cases around the country, such as Lake Jukajärvi (Mustonen \& Mustonen 2013a), demonstrate. This North Karelian lake was lowered for the third time in 1959 (Tikkanen 2002a: 37, 2002b) to increase the amount of farmland (Maaranen 2002). Local fishermen opposed the action, mostly on the basis of potential damage to fisheries and impacts on other uses of the lake, such as bird hunting. Lehtinen (2000) and Tikkanen (2002b) confirm that no 'peaceful' balance has been found between the different uses of aquatic resources.

Sarmela (1991) offers a bridge in this cultural change from 'traditional' hunting-fishing economies into the industrial age, with ensuing changes to the relationship with nature. He uses bear hunting as a case to demonstrate the shift in perspectives regarding nature as a system of reciprocity to a resource that humans can utilise. The central element for the purposes of this paper is the environmental impact that different Finnish practices may have on nature and a given ecosystem. Mustonen (2009) argued that while such development may have taken place, the community of seiners in Eastern Finland demonstrate a more complex reality, where the elements of the hunting-fishing view of nature have been partially preserved; it is being maintained by the contemporary fisheries.

For the purposes of this paper, three regions and cases are explored to investigate the preservation and status of such endemic time-spaces in relationship to aquatic ecosystems. It is argued that the hunting-fishing view of lakes contains an endemic 'regime', a long historical continuum that Finns have had (Raussi 1966; Saiha \& Virkkunen 1986), and, in local communities which continue the practice, may still possess. It portrays the varied, rich heterogeneity that Thrift and May (2001) identify as a part of a time-space.

The cultural process, deriving from the utilisation of water bodies for farming in Finland (Maaranen 2002), has developed from an agricultural complex into a technological-industrial (or -economic) use of aquatic systems (Antikainen \& Vartiainen 2002; Husso \& Raento 2002a), with direct and immediate environmental consequences (Tikkanen 2002a: 36, 2002b). As Lehtinen (2000) demonstrates, this technological-industrial use contains lexicons and a naming of nature that begins to be vastly removed from the local community's understandings of the same places, as in the case with the 'classification' of marsh-mires.

Illustrated by earlier research (Mustonen 2013a, 2013b), the majority of the decisions regarding Finnish aquatic catchment areas, including zoning and environmental permitting, are based on scientific expert knowledge (Husso \& Raento 2002a), linear times and spaces, and rational worldviews (Lehtinen 2010: 109). "Nature management" dismisses cultural and social diversity, and replaces it with science 
and nation-state-dominated views (Mustonen 2013a).

In this time of rapid change (Pretty 2011; Jeffries et al. 2013), a fundamental rethinking is necessary in order to guarantee the survival of local cultures and ecosystems (Lehtinen \& Mustonen 2013). Husso \& Raento (2002a: 161) argue that the cultural geography of Finland is being 're-shuffled' and in this process the traditions of Finns are receiving renewed interest.

Consequently, an engagement and respectful work with the people and their endemic timespaces may provide exciting and crucial ways of detecting rapid ecosystem degradation (Mustonen 2013a) or the identification of the sites of ecological change (Mustonen 2013b; Mustonen \& Feodoroff 2013). This is in line with what Lehtinen (2010: 119) calls geographers to do; to conduct "a serious assessment and ongoing self-critique through constant re-formulation of our customary conceptual frameworks in the effort to open intellectual space for other views and ways of interacting with the world."

Maaranen (2002) states that cultural landscapes are subjective interpretations of their elements. Therefore, the practical aspects of including such endemic time-spaces in land use planning, permitting, and zoning includes the production of user maps (Hudson 2001; Mazzullo 2013). While they are insufficient for portraying the entire range and depth of human agency regarding water bodies, the key aspects of endemic time-spaces, fixed on maps, in careful and respectful cooperation with the people possessing and guiding them, can offer ways to avoid the ecological damage and to open doors of emergence to the hidden, deep connections that Finns have with their lakes in this time of change and development.

Maaranen (2002: 101-102) agrees by saying that reconstructions of past land use and settlement patterns offer a means to understand cultural landscapes and changes in them. This paper seeks to illustrate the characteristics of these endemic time-spaces in Western and Eastern Finnish watersheds. Central to this is the concept of apaja (Pennanen 1976, 1979, 1986; Nieminen \& Mustonen 2004; Mustonen 2009) within the cultural complex of Finnish fisheries.

Apaja can be defined as a place of catch or fishery (Pennanen 1979), but it may also refer to a plentiful catch. Mustonen (2009) documents the multiple roles apaja has for winter seiners. It is both a place and a time, during which the winter seine is pulled. It may consist of up to five 'scapes' of simultaneous knowing: the bottom of a lake, a water pillar, the underside of the ice, the upper part of the ice, and the visible landscape at the specific site of harvest (Mustonen 2009). '(Land)scaping' (Lehtinen 2010: 118) however compresses the reality as experienced through the fisheries' practice.

Apaja is also the customary ownership of the fishermen. An apaja is named as a hydronym (Great Lakes Indian Fish \& Wildlife Commission 2007; Heikkilä and Fondahl 2010), and can demonstrate layered human use and presence on a lake, for example, through an event that happened at the site, or a story from a long time ago, or a marker of cultural change, as is the case with those apaja sites from Lake Näsijärvi which reflect the arrival of Karelian settlers (Suomela 1976; Maaranen 2002: 106) to the region of Häme after the war (Nieminen \& Mustonen 2004) (Table 1).

Heikkilä \& Fondahl (2010: 113) indicate that, in cases of other boreal cultures, hydronyms convey specific attributes of a place, its resource potential and associated practices. Hydronyms relate a people's culture to the water and ways they use it.

Nieminen \& Mustonen (2004) illustrate how the documented apaja sites (Fig. 1) of the northern part of Lake Näsijärvi reflect the seasonal uses of the lake in seining in the case of western Finland. Additionally, apaja sites reflect different fish species to be harvested as a part of the seasonal round on the lake. Seiners also endemically rate and qualify different apaja sites according to their productivity. Like the case of Sámi notions of reindeer (Lehtinen 2010), the apaja is hard to convey as a culturally relevant time-space, yet essential as an element of the surviving endemic aspect of a relationship with a lake.

The time-spaces endemic to Finnish aquatic regimes will be explored by analysing material from three projects in these areas, with the scientific purpose of exploring how such time-spaces survive, and are maintained by predominantly rural populations along these catchment areas, rivers and lakes. More specifically, differences in the Western-Eastern axis of these practices are expected to illustrate different responses to mapping, documentation, and preservation of local knowledge. 


\section{Theoretical framework of Finnish endemic time-spaces}

The notion of "endemic time-space" has emerged in the evolving global scholarship regarding the ways indigenous and some local societies around the world are organizing their socio-ecological realities (Mustonen 2012). In northern geographical literature, one way of exploring the endemic timespaces are the different, yet intimate, contacts that local culture have with their places. Heikkilä and Fondahl (2010) explore one such case with the Tl'azt'en Nation from Canada. They (2010: 106) argue that hydronyms and toponyms, as expressions of culturally-relevant ways to organise timespace, "anchor indigenous identity to...places". Lehtinen (2010: 106) identifies a 'tension' between how local cultural practices and state/technological-industrial governance understand a place. In his view (2010: 107), the act of naming can be read in a political context, where the same place, depending on 'whose' naming-power is more dominant, can produce that place, identity, and relationship. In Finland it is the Sámi people who are considered to be indigenous by international law (Husso \& Raento 2002b). Therefore culturallyrelevant endemicity of time and space often focuses on them in Finland. This paper explores these concepts, their exportability and the applicability that Smith (2005) refers to in the context of Finns with different aquatic ecosystems.

The concept of endemic time-spaces (Lehtinen 2000 for marsh-mires; Thrift \& May 2001; Smith 2005), also referred to as 'earthviews' (Lehtinen \& Mustonen 2013), and cultural readings of landscapes are largely hidden from and lacking in environmental planning, zoning, and assessments of watersheds in Finland. Concurrently, the plans for various industrial uses of aquatic socio-ecological systems, here 'regimes', in Finland are based on linear worldviews and understandings of time and space. 'Regime' may contain the notion that the relationship with nature is one of subjugation and exploitation. The particular cultural 'regime' focused on in this paper is built on cohabitation with the bodies of water that the Finnish fishing populations seem to demonstrate.

Lehtinen (2000) proposes that in the case of marsh-mires, specific, endemic time-scapes or 'mirescapes' based on gathering economies exist, which are mostly hidden from the official or public views. In fact, local people possessing them suffer from double disassociation according to Lehtinen (2000): firstly, they are excluded from the decision-making regime which transforms marsh-mires into zones of resource production, and secondly, they have different lexicons of engagement with marsh-mires than the classifications of categorized science (Husso \& Raento 2002a: 262).

Lehtinen (2011) offers a way forward; according to him, there is a need to engage with the particular geographies of local knowledge (Berkes 1999; Luotonen 2006), also known as concentric readings of time and space. Instead of increasing their marginality, geographers should embrace these "zones of withdrawal" (Lehtinen 2011: 18). Great Lakes Indian Fish and Wildlife Commission (2007) explains that the problem persists also in North America. Lehtinen and Mustonen (2013) argue that a new engagement can be achieved methodologically by applying 'earthviews', the oral and optic histories of the local people in a manner that is respectful for their cultures, situated knowledges and co-authorship (Smith 2005; Great Lakes Indian Fish \& Wildlife Commission 2007), co-learning and co-production of knowledge (Lehtinen 2011). By exploring cases and the significance of endemic time-spaces within two major watersheds in Finland, the Kokemäenjoki and Vuoksi catchment areas, the qualities and characteristics of such surviving and ongoing cultural readings of aquatic ecosystems will be illustrated.

This view rests on the recently adopted methodology of Finnish community-based research (Mustonen \& Feodoroff 2013) in documenting ecological change. Anthropology and other disciplines have produced maps of human activities, including fisheries (Vilkuna 1974; Turunen 1976) for decades in Finland. However, by allowing the fishermen and residents of watersheds to emerge as co-researchers and co-authors (Mustonen 2013a), a deeper reading of a lake or a river under change may emerge.

This hidden, often forgotten realm of lived relationships (Lehtinen 2000) with water challenges the measurement-bound understanding of a catchment area and may allow potential new avenues of study and reforms in zoning and land use, which impact these socio-ecological systems. To narrow the scope and extent of the present article, it is limited to the aquatic ecosystems, here defined as rivers, lakes, the Baltic Sea, and marsh-mire ecosystems (Lehtinen 2000). Terrestrial time-spaces will be explored in future publications. 
At the core of describing endemic time-spaces is the notion of human land (here, water body) use and occupancy (Hudson 2001; Great Lakes Indian Fish \& Wildlife Commission 2007; Lehtinen 2011; Mazzullo 2013). Pälsi (1924) was amongst the first researchers in modern times to use maps to document and explain the endemic time-spaces and ice uses of the Karelian Suursaari seal hunters in the 1920s. He was decades ahead of his colleagues in North America, who began land use and occupancy studies connected with land claim negotiations in the 1970s (Hudson 2001). While the initial purpose of the mapping exercises referred to by Pälsi (1924) and Hudson (2001) are different, both try to convey unseen uses of an area previously unknown to the public.

While the North American land use and occupancy studies were and are connected with issues of human inequity and legal rights for land ownership, Pälsi (1924) acted, for the most part, driven by scientific curiosity to investigate the life-ways of the little-known community of Suursaari seal hunters. Since then such activities have become standard in the Western Hemisphere in countries with significant indigenous populations (Hudson 2001; Great Lakes Indian Fish \& Wildlife Commission 2007), especially in the Arctic and sub-Arctic. The mapping of indigenous topo- and hydronyms is done also in areas of North America which are under a treaty (Great Lakes Indian Fish \& Wildlife Commission 2007). Land use and occupancy mapping is, to a large extent, missing from Finnish debates on questions of how, as is the case in the present paper, aquatic ecosystems and human societies interact over large historical periods as a part of multi-faceted ecosystems. A question of relevance therefore emerges: to what extent is it applicable to install land use and occupancy studies in the Finnish context when legal land use debates are not fuelling them.

The need to document and explore land use and occupancy issues in Finland arises partly from the same scientific curiosity that initiated Pälsi's (1924) and his contemporaries work. We still do not adequately know how Finns relate to their watersheds and aquatic regimes. Simultaneously, the industrial interest in these regions, places, and spaces is overwhelming (Lehtinen 2000; Maaranen 2002; Lehtinen 2011; Mustonen 2013a, 2013b). Urgent new ways to understand, navigate, and solve the overlapping interests are needed (Lehtinen 2011). Therefore land use and occupancy studies, properly adapted from their foreign contexts, combined with the engagement with oral histories (Macdonald 2000) situated in the areas in question may provide a crucial new evidence of human relationships and presence.

Hudson (2001) warns geographers about a trap. While two- and three-dimensional maps and databases convey a version of reality bound on maps and fixed on demarcated territories (Antikainen \& Vartiainen 2002: 186), they do not convey the multi-dimensional reality many indigenous and local communities retain in their connections with their places and the ecosystems they co-habit (Sheridan \& Longboat 2006; Great Lakes Indian Fish \& Wildlife Commission 2007; Lehtinen \& Mustonen 2013). Mazzullo (2013), reviewing the disputes of forestry in the Finnish Sámi community of Nellim, demonstrates that maps are indeed, even with their shortcomings, effective tools for negotiations on different uses of lands and waters. Lehtinen (2011) agrees with Hudson's (2001) view and acknowledges that 'landscaping' can be a colonial act if we are not aware of the concentric, particular geographies of a place.

In the case of Finland, there are many ethnic groups which possess prehistorical and historical endemic time-spaces within the contemporary borders of the country (Husso \& Raento 2002b). These include, among others, the three Sámi nations of Skolts, Inari and North Sámi, the Karelians in the extreme eastern parts of the country, the Swedish minority along the western coastal areas of the country, the Roma(ni) (Pulma 2012), and lastly and most heterogeneously the Finns themselves (Husso \& Raento 2002b). Husso \& Raento (2002b) argue that many of these groups have preserved "regional hearths". While such divisions can be addressed and criticized from multiple viewpoints, the Finns are not indigenous people by law. Contested issues may be, for example, various notions and definitions of Sáminess, locations along urban-rural land uses, and so on (Husso \& Raento 2002b).

For the purposes of this article, we can summarize that the land use and occupancy discussions in the present are primarily concerned with the indigenous Sámi and their struggles to recognize title, possible ownership, and stewardship of their home regions (Mustonen \& Mustonen 2011; Mustonen 2012; Mustonen \& Feodoroff 2013; Mazzullo 2013). Such debates also rage on in neighbouring countries, including Sweden (Syrjämäki \& Mustonen 2013). While the Sámi have begun to investigate this topic, and have also been 
the targets of land use based science efforts for hundreds of years, the role, extent, and qualities of the Finnish endemic time-spaces and the land/ water-uses they contain, remain an enigma that has been infrequently explored, especially in recent times (Mustonen 2013b).

For certain aspects of communal fisheries, the past and present are a vehicle to explore the topic. Sarmela (1991) demonstrates the overall cultural change associated with nature, and the increased role of farming in that process. Fisheries (Mustonen 2009), especially ongoing seining (Pennanen 1979), challenge Sarmela's analysis of a total change by preserving the elements of a huntingfishing view on nature.

In addition to the large corpus of cultural texts held by the Finnish Literature Society (Suomalaisen Kirjallisuuden Seura 2014), some books, such as Raussi (1966) and the works of Into Sandberg (Saiha \& Virkkunen 1986), contain descriptions of this endemic regime while it was to a large extent still functioning. To deepen the role of the endemic time-space regime, two authors practicing the system can be referred to. First, Raussi (1966) provides a clear description of such time-spaces. At the core of the 'system' are the seasonal, communal fishery activities of a given community. Care should naturally be taken when modern terminologies, such as regimes and 'system' thinking, are imposed on traditional governance structures (Arctic Council 2013: Introduction to indigenous knowledge).

Raussi (1966: 67-79) provides a clear description from the community of Virolahti, located on the Finnish coast of the Baltic Sea, from the early 1800s. Communal decisions regarding the leadership, family harvest areas, seasonal aspects of seining, and other features of this fishery are described without parallel in their details of how Finns used to fish. His views constitute an insider's perspective of these practices.

Secondly, Saiha and Virkkunen (1986) document the cultural views of Into Sandberg. He was a fisherman and author from the western coast of Finland near Pori. He goes to great lengths in sharing his endemic time-spaces of the fisheries, winds, skies, weather, sea, coast, and forests of his native region. If Pälsi (1924) observed the seal hunters as an outsider on the now ceded Suursaari Island in the 1920s, Sandberg lived inside his culture and told of it in both oral history and through his writings in media and books (Saiha \& Virkkunen 1986).
Raussi (1966) and Sandberg (Saiha \& Virkkunen 1986) also explain the elements of the Finnish endemic customary organisation of fisheries based on the family use areas and traditional notions of 'ownership'. In North American fishing societies, such as the $\mathrm{Tl}^{\prime}$ azt'ev Nation, a similar way of organising harvest is called keyoh (Heikkilä \& Fondahl 2010).

Raussi's materials constitute elements of local water stewardship. Käki (1969: 19-20) offers a rare documentation of such customary system that was recognized by the Finnish state. He writes that the island of Ulko-Kalla, located on the Western Baltic Coast of Finland, has a self-autonomy: "Kalla has a self-government. All fishermen can decide to certain extent their own issues. They also have a limited juridical power. No person can be sent to jail, but can be driven away from Kalla for good."

The surviving apaja system with its hydronyms in use in Lake Puruvesi (Pennanen 1979), one of the cases of this paper, is a living example of an endemic understanding of a traditional stewardand ownership associated with a lake (Mustonen 2009: 171). This endemic aquatic regime received attention from academic scholars early on. Sirelius (2009) launched the Finnish academic inquiry into fisheries, both in Finland and in the perceived homelands of the "Finno-Ugric" people, from West Siberia to the Baltic lands. He focused first and foremost on the technical aspects of the fishing equipment and regional differences of such tools. Some observations made by Sirelius (for example 2009: 242) contain information about the endemic organisation of seining crews, seasonal harvests, and sites of fisheries, which provide a continuum in the academic review of the practice, and complements Raussi's (1966) observations as an insider.

A large body of academic material has been produced in fisheries studies in Finland. They have included some user maps, which have appeared in land use documentation since the days of Pälsi (1924). There are a few examples that specifically focus on the land/water/ice use documentation and local Finnish knowledge, like Vilkuna's (1974) work which is a prominent example of the Kemijoki catchment area and salmon harvest. For inland waters, Virtaranta (1976) provides a clear view of the White Sea Karelian communal lake fishery in the community of Suomussalmi. In the 2000s, Nieminen and Mustonen (2004) explored the seining territories of Western Finland's professional fishermen using community-based methods 
and Mustonen (2009) carried out a similar study in North Karelia, while Luotonen (2006) investigated the Finnish Baltic coast.

Luotonen (2006) argues that the endemic timespaces (Thrift \& May 2001) manifest through the residency of local people, in this case on the Baltic coast. Mustonen (2009) argues that in the situation where cosmology has been broken, traditional activities, such as non-motorized winter seining reconnect people to the land, ice, and waterscapes through the doing itself; this topic of loss and return is also being discussed by Sheridan and Longboat (2006) for the Mohawk people in Canada. The impacts of climate change triggered an interest in the local traditional knowledge of the coastal Finland in the early 2000s when Mäkinen and Mustonen (2004) provided maps and accounts of the Swedish-Finnish long duration seal hunting journeys on the North Baltic throughout the 1900s.

To explore the aquatic, endemic time-spaces of contemporary Finland and its communities, a watershed-based view needs to be adopted. Those communities and individuals who are situated along the catchment areas of various water-bodies, it is argued, may possess the remnants of the Finnish endemic time-spaces (Mustonen 2013b). After World War II, a group of Karelian seiners arrived in Päijänne in Central Finland. Suomela (1976) describes this group and their knowledge of fisheries. The seiners seem to have considered the local fishery to be 'primitive' and underdeveloped in comparison with the large nets and methods they brought with them from Lake Ladoga. Suomela (1976) links this to the position the Karelians enjoyed at the forefront of net development in the early 1900 s due to their close proximity to St. Petersburg and other trade centres, as opposed to the inland location of the Päijänne fisheries. This opens the complexities of endemic practices and their reviews in the contemporary Finnish context.

Based on the earthviews (Lehtinen \& Mustonen 2013) Finns have, we can deduce some characteristics of culturally-relevant, but for the most part, hidden readings of a waterscape still in existence. Such endemic time-spaces are threatened by the industrial uses of the catchment areas. However, it is in the last 50-60 years that the speed, scale, and negative ecological impacts of linear time-spaces and production regimes have left deep marks on these catchment areas (Lehtinen \& Mustonen 2013). We can assess the local communities and those individuals possessing endemic readings as the subjects of actions and power directed towards the exploitation of these locations for various purposes, whether it be for profit, for "the common good" or for flood control.

Common industrial uses of watersheds include hydroelectric power production, forestry, mining, pulp and paper manufacturing, agriculture, roads and infrastructure, and urbanisation. In this paper, the role of peat production (Rytteri 2002; Mustonen 2013a) on the marsh-mires stands out as a case in point and is prominently featured in the two catchment areas and cases within them. To summarize, most of the time industrial uses and impacts on the watersheds result from the linear, demarcated understandings of a reality (Vilkuna 1974; Mustonen 2013b), which do not include the endemic timespaces of the local people.

Therefore, such alternate readings, rooted and developed in their places and local cultures (Lehtinen \& Mustonen 2013), are in direct conflict with the industrial demarcations of land and zoning (Hudson 2001). While in theory such juxtaposition helps to analyse the cases and local knowledge and endemic time-spaces, reality is far more varied, meshed, and complex. The distinction between imposed, demarcated uses of the catchment areas and endemic readings (Sarmela 1991; Lehtinen 2000) are 'separated' into opposite, binary categories for the purposes of the analysis in the paper, but, for the most part, they remain hidden (Lehtinen 2000). Lehtinen (2000) goes further to argue that there is a double disassociation taking place - local communities in rural areas are removed both from the modern decision making and "science talk" which is used to demarcate, utilize, and harvest various aquatic ecosystems.

\section{Methods}

To shed light on the hidden (Lehtinen 2000) realities of Finnish endemic time-spaces and to explore them, two catchment areas and three cases are used to illustrate the quality and characteristics of such systems. Methodologically, this is accomplished using mapping of endemic time-spaces, oral histories, photos, and media accounts. These contemporary time-spaces manifest best through the reciprocal relationship that Finns have with their fisheries.

The first case demonstrates the endemic timespaces associated with the apaja sites by mapping water-uses and hydronyms from Western Finland. It is based on a nine-year engagement with fisher- 
man Ahlgrén, between 2004-2011 to produce apaja maps from the northern part of Lake Näsijärvi. An earlier non-analysed, Finnish version of maps was published in 2004 (Nieminen \& Mustonen 2004). Additional methods included the documentation of oral histories with Ahlgrén from 2002 to 2010 (Snowchange Ahlgrén Oral History Tapes 2002-2010).

In the second case, the use of both oral and optic histories as a village-based watershed restoration activity illustrates how the endemic time-spaces, and concern for the loss of ecological habitat, can be used to complement scientific tools. This helps to determine how, what, and where things have changed, as well as what it means, both from the endemic frame and from a more generalized knowledge production. Oral history interviews were conducted with the community people in two fieldwork periods, in October 2013 and in February 2014. Narrative analysis (Cortazzi 2001) was employed to identify key markers in the materials. Each visit lasted a week and the interviewed fishermen had been selected beforehand by the fishermen's organisation of Lake Kuivasjärvi. The previous literature of local knowledge (Valonen 1945; Laaksonen 1999) in the area was also reviewed. Local people wished to be quoted anonymously and the case study was funded by the WAPEAT - Water Management and Peat Production: From Relevant Facts to Effective Norms -project.

Thirdly, a surviving seining culture in Lake Puruvesi is reviewed by utilizing literature from the community from the 1970s (Pennanen 1976, 1979, 1986) to the 2000s (Mustonen 2009), participant observation from 2005-2014 (Meriläinen-Hyvärinen 2008) as a member of the seining crew (Mustonen 2014a) and lastly, in different ways that the seiners react to the mapping of their apaja sites as contemporary holders of these sites, knowledge, and culture. Complementing materials are derived from a long-running oral history project with the fishermen and references to scholarly materials from the 1970 s to the 2000s will be made. A total of six fishermen were collaborators here and allowed their names to be used. Original research was conducted as a part of a doctoral dissertation (Mustonen 2009) and then continued using long-term observational research.

By highlighting the Western and Eastern watersheds and cases from them, the various stages of endemic time-spaces can be seen. Central to the paper is the manifestation of these concepts using the communal seining with its apajas, and its associated hydronyms.

\section{Case of northern part of Lake Näsijärvi seining in the Kokemäki watershed}

The Kokemäenjoki River catchment area is a major watershed in Western Finland, with a total territory of $27,000 \mathrm{~km}^{2}$. The river flows through the regions of Pirkanmaa and Satakunta, and bypasses several human settlements along its stream before discharging in the Baltic Sea close to the coastal city of Pori. Today this former salmon territory suffers from various industrial impacts, including hydropower, agriculture, forestry, pulp, and mining activities as well as peat production. The catchment area is rather young, approximately 6500 years old (Hämeen ELY-keskus 2014).

Lake Näsijärvi is a major lake in this catchment area (Nieminen \& Mustonen 2004). Simo Ahlgrén (1924-2011), a professional fisherman, who lived on the shores of the lake for most of the $20^{\text {th }}$ century, documented the summer seining apaja catch sites of the regions' fishermen throughout the 1940s (Nieminen \& Mustonen 2004: 52). Ahlgrén was deeply involved in the development of fishermen's organisation, competitions, and union activities throughout the 1900s. In the early 2000s, these apaja site maps were digitally drawn and reproduced.

Ahlgrén was like Sandberg (Saiha \& Virkkunen 1986) in the sense that he mastered the skills of summer seining while at the same time writing texts and speeches, and making maps and paintings related to his in-depth knowledge of Lake Näsijärvi. The fishermen also knew each other.

By exploring the apaja (Mustonen 2009) catch sites of the northern part of Lake Näsijärvi we can see the detailed view of a seiner regarding a Finnish lake and its features. Each site has a name, some of which are linked to time immemorial or early historical times. They are sustained by the seining practice and, for the most part, were orally transferred. A site also possesses knowledge regarding the type of fish that should be harvested in the repeated cycles of the moon and different weather, including winds (Nieminen \& Mustonen 2004).

More specifically there are 101 apaja sites on the northern part of Lake Näsijärvi. There are 'general' sites for all fish species and numerous specific sites for European smelt (Osmerus eperlanus), including spawning locations, and vendace (Coregonus albula). These schooling fish constituted primary catches in the 1940s when the seining was 


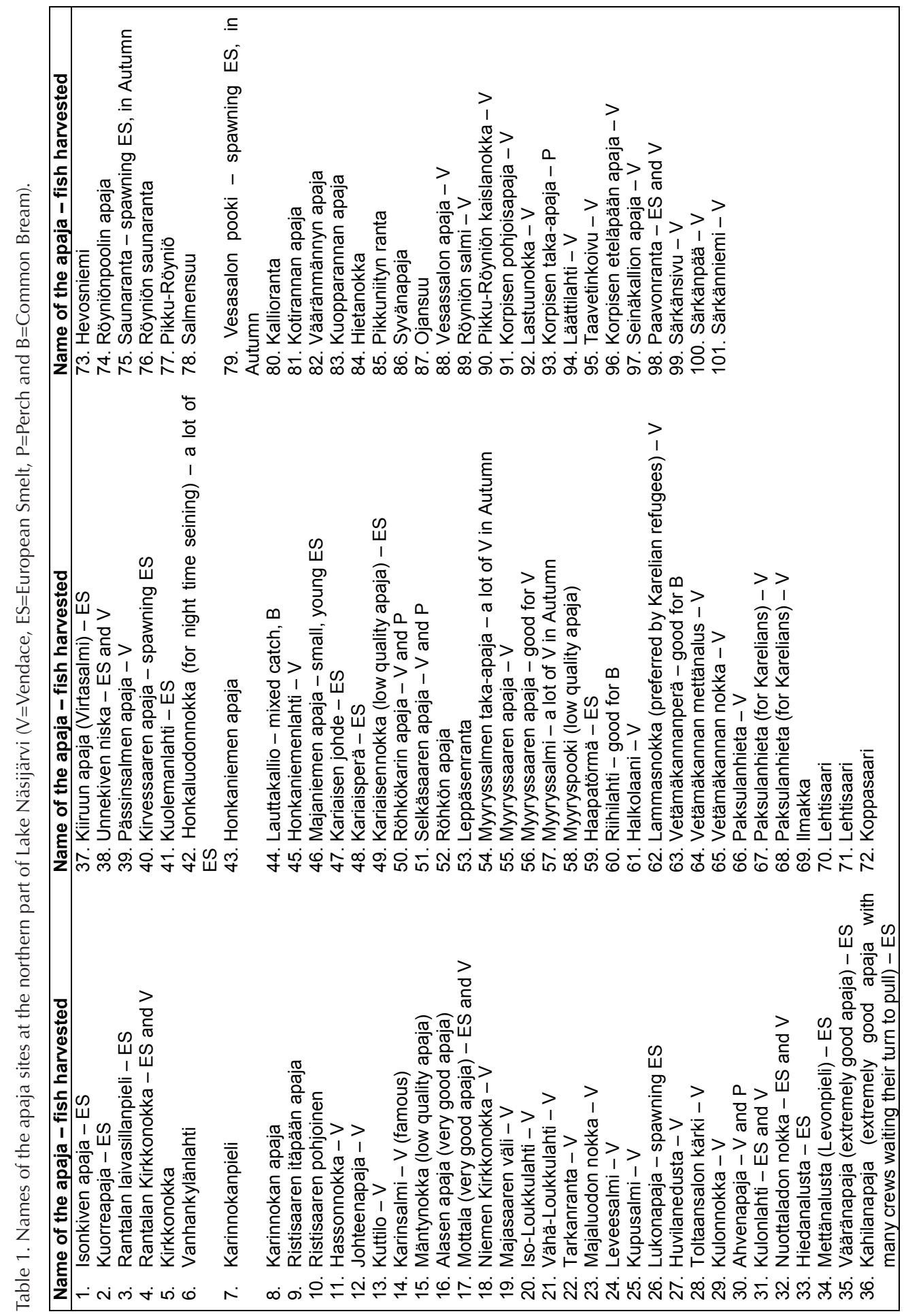




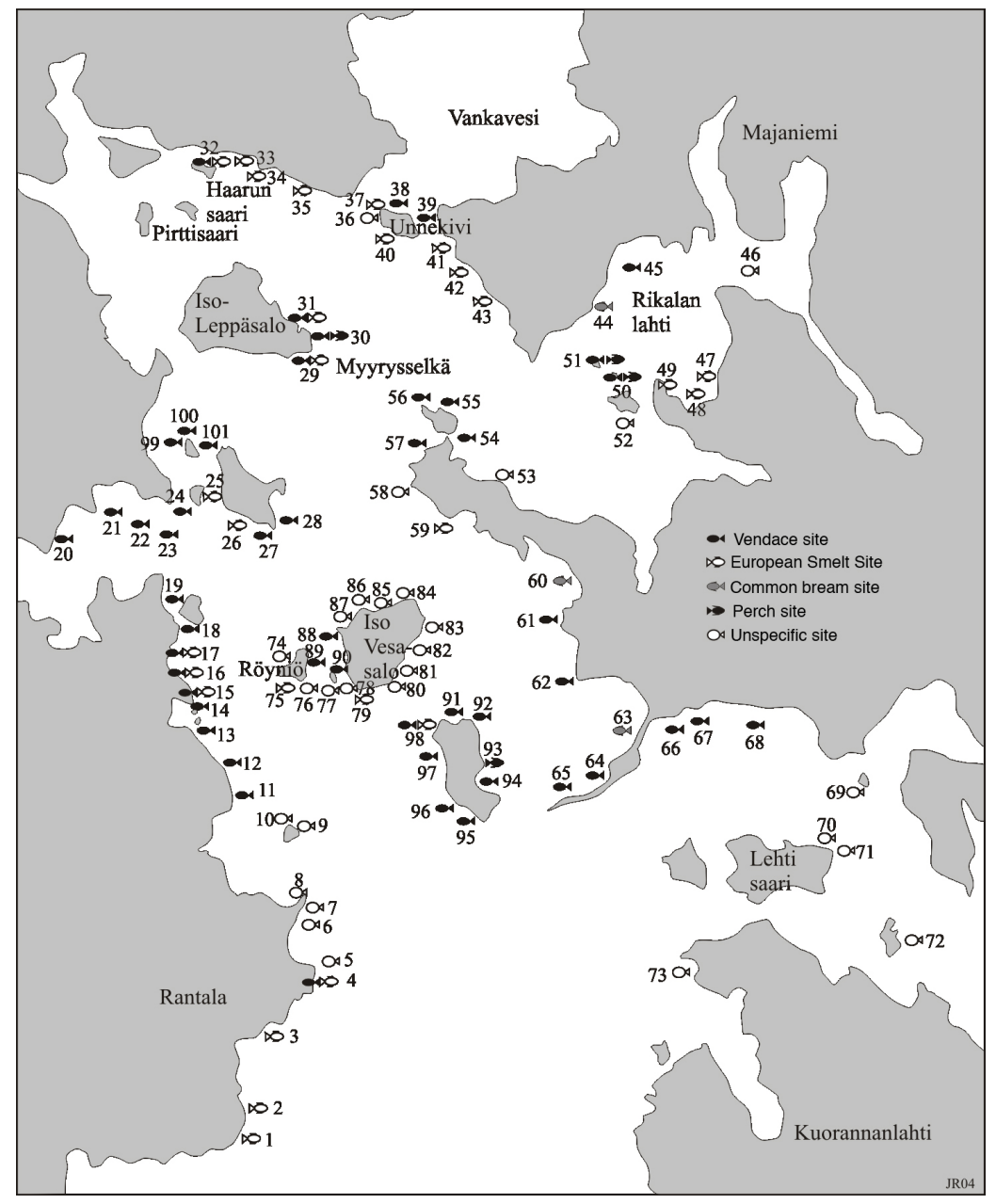

Fig. 1. Endemic time-spaces of Lake Näsijärvi and Kokemäenjoki River catchment area manifesting through the dozens of different species-related apaja catch sites. This map portrays toponyms as recorded in the 1940s. Contemporary spellings include: Iso Leppäsalo = Iso Leppisalo, Haarunsaari = Haarunsaari, Iso Vesasalo = Iso-Vesassalo, Kuorannanlahti $=$ Törölänlahti.

Adapted from Mustonen and Nieminen (2004). already a mixed fishery of both subsistence and economic activities. Other species identified for specific apaja sites include common bream (Abramis brama) and perch (Perca fluviatilis).

Names, more specifically hydronyms, of the sites contain information about features of the lake bottom and the lake (such as Isokivi - Big rock, Syvänapaja - a deep site), geographical locations (i.e. Laivan sillanpieli - Side of the dock towards the ship), family and individual naming and ownership (i.e. Kahilanapaja of the Kahila family, Röyniö for the seining crew of Röyniö), and sites that the new arrivals from Karelia (Suomela 1976) started to utilise (i.e. Lammasnokka) (Nieminen \& Mustonen 2004).
Therefore, apaja sites are both localities possessed by the fishermen and connections as well as manifestations of time-spaces of natural watersheds and the various ecological cycles inherent in these catchment areas. Some fishermen consider the apaja sites to be their most precious possession (see more in Mustonen 2009), a notion present also as a customary ownership in Käki (1969) and endemically-controlled regime in full operation in Raussi (1966).

A distinct feature of the Kokemäenjoki River watershed is the summer seining. For the most part, summer seining ceased in the 1950s. Only the memories and maps of a vast endemic aquatic regime (Maaranen 2002), once controlled and mas- 
tered by the late Ahlgrén and his colleagues, remain. As Hudson (2001) and Lehtinen (2011) point out, such maps can only pass on information in their two-dimensional beings, but they do not convey the multiple, endemic customary ways of engaging and interacting with such time-spaces and the fish inherent in them.

\section{Case of Lake Kuivasjärvi in the headwaters of Kokemäenjoki River}

Northeast of Lake Näsijärvi is a small lake, Kuivasjärvi. Kuivasjärvi belongs to the upper reaches of the Kokemäenjoki River watershed (Hämeen ELYkeskus 2014). The lake catchment area has been the target of large-scale industrial peat production since the 1970s. Before that the lake and watershed were subjected to ditch drainage for forestry purposes: "After the war ditching took place all over the watershed" (Snowchange Kuivasjärvi Oral History Tape 151013). The lake water levels were lowered in 1904 (Valonen 1945).

The lake is known for its rich cultural heritage, pre-historic Sámi populations, and place names (Valonen 1945; Laaksonen 1999: 126-127), and for having a distinct character as a 'border' zone between the low-lying lands of Pohjanmaa and the once-forested, hilly region of Häme. Valonen (1945) quotes Elias Lönnrot from the 1800s who identified the region to be very rich in folklore and ethnographic materials. Valonen (1945) writes that around Lake Kuivasjärvi the knowledge regarding the deities of the forest Finns, such as Tapio, Liekkiö and so on, have been preserved:

\begin{abstract}
"My father told me that the people of Hiisi [one of the old Finnish spirit-gods] travelled on Lake Kuivasjärvi in winter time. I do not remember the kind of noise they made, but old people said that they are there, moving." From a conversation with a 92-year-old subsistence fisherman, Kuivasjärvi, Snowchange Kuivasjärvi Oral History Tape 120214
\end{abstract}

Additionally, this knowledge survived until the 1930s fairly intact (Valonen 1945). Laaksonen (1999) agrees and confirms the special role the watershed has as a traditional cultural region.

Since August 2013 the catchment area of Lake Kuivasjärvi has been the focus area of natural sciences and local knowledge restoration project and people's movement (Ylä-Satakunta 2013). The ini- tiative is one of the first to utilise endemic timespaces, oral histories, water/land use, and occupancy mapping in water-body restoration activities in Finland. The first results from the oral history materials confirm what Laaksonen (1999) presents - the fishermen and other local people still remember the endemic uses and relationships with their lake.

The subsistence fishermen of Lake Kuivasjärvi who were born in the 1930s remember seining: "They used to seine here in the 1920s and 1930s, still." (Snowchange Kuivasjärvi Oral History Tape 151013). According to them, the place names on the western bank of the lake can still pinpoint the harvesting sites. Seining, both winter and summer, was reintroduced on the lake in the mid-2000s, but has not become a resident cultural practice, at least not yet (Mustonen 2014b).

As a part of the ecological restoration project, oral histories were documented along the lake between October and February 2014 to investigate the surviving aspects of endemic time-spaces and their manifestations on this water body. Additionally, place names were analysed using fishing diaries collected for historical catches between 1968 and 1991 and contemporary catch diaries. This period was chosen, because it coincides with the time of aggressive peat production expansion into the watershed. Lastly, a set of optic histories (Mustonen \& Feodoroff 2013) were developed through the use of photographic material spanning from the 1930s to the 1980s to investigate direct ecological change resulting from the increased use of fertilizers, peat production, and eutrophication (see Tikkanen 2002b for national trends) processes throughout the $20^{\text {th }}$ century (Fig. 2).

After the seining had been ceased, the endemic time-spaces of Lake Kuivasjärvi manifest best in the fish trap fishery along the lake (Fig 3). The activity continues to this day and as optic histories from the 1950s record, it is an old practice and a key activity within the cultural fishery of the Kokemäenjoki River catchment area: "Fish traps were instrumental in our family harvests in the 1940s and 1950s". (Snowchange Kuivasjärvi Oral History Tape 161013).

Traditionally, the locations of these fish traps were family-owned, and carefully chosen to catch spawning pikes and perch all the way up to the 1970s (Snowchange Kuivasjärvi Oral History Tape 161013). Through the first round of oral history documentation in the autumn 2013, endemic time-spaces were related to many characteristics, 


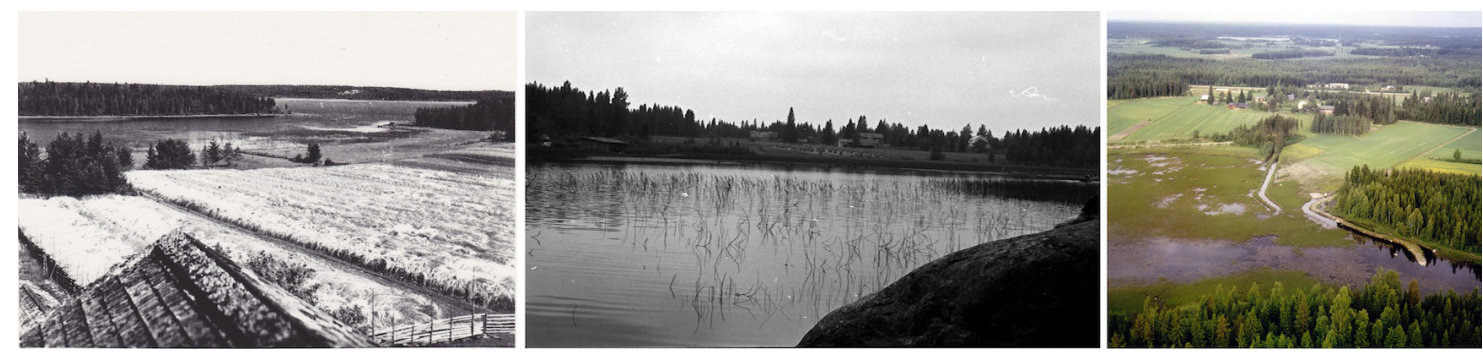

Fig. 2. A set of three photographs, i.e. visual-optic histories documented in the same locality on the western bank of Lake Kuivasjärvi close to the island Saarelansaari from 1947 to 1970s, illustrate the rapid ecological change and proceeding eutrophication of the lake as a result of human-induced activities. Photos by Mauri Kallio 1947 (left), Erkki Saarela 1975 (middle) 1979 (right).

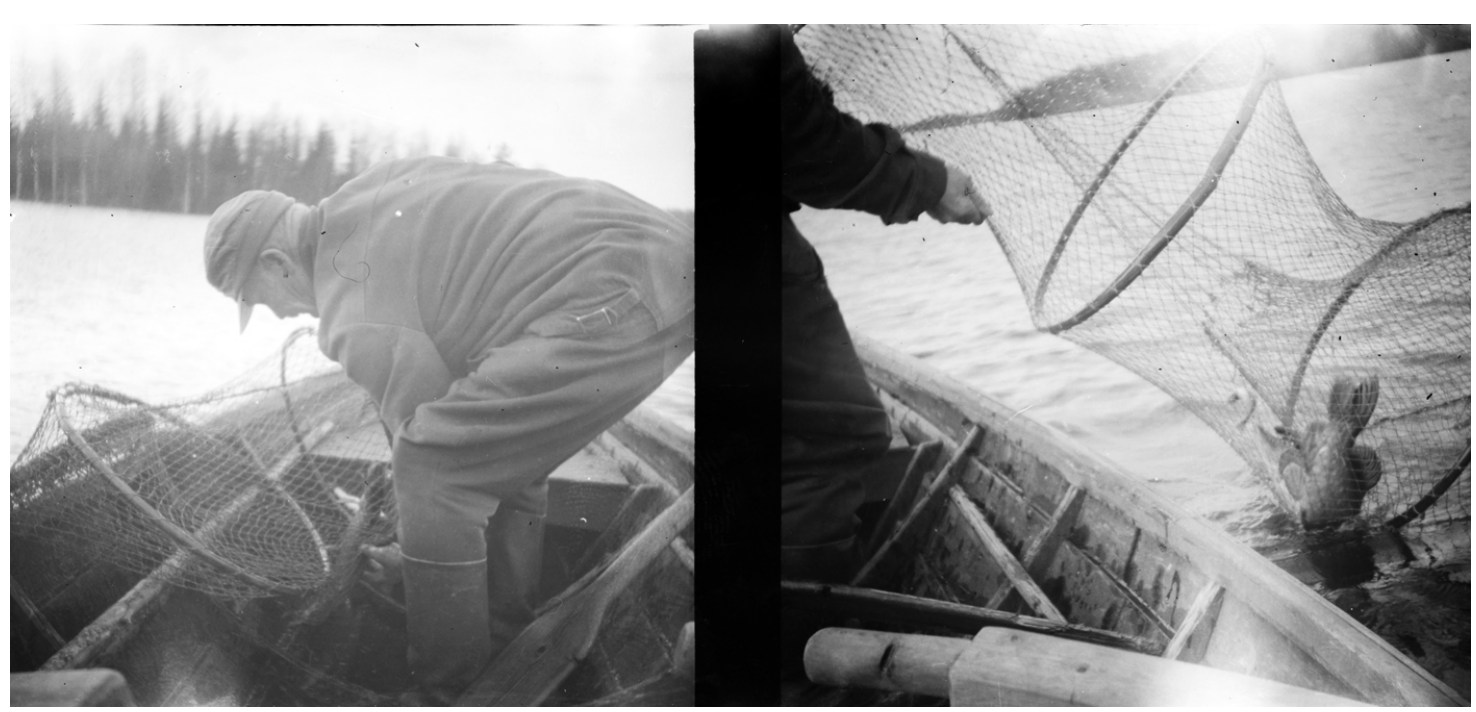

Fig. 3. The harvest of spawning northern pike using fish traps on the western shores of Lake Kuivasjärvi in the spring 1957. Photos by Erkki Saarela 1957.

like weather prediction, place names, family-controlled customary locations along the lake, berry picking and hunting areas of mire-marshes, which had been lost as the industrial ditching to drain areas began.

As a mechanism to explore and assess ecological change in a water body, relationships between local people and three different fish species emerged as key indicators of endemic time-spaces. First, the interviewed people explained the special role northern pike (Esox lucius) has in Lake Kuivasjärvi (Snow- change Kuivasjärvi Oral History Tape 161013). If a certain fish is caught, it can be used to predict things to come. The special characteristics of pikes in Lake Kuivasjärvi were documented, but the people who still understood these aspects of traditional knowledge as being relevant considered the more detailed information to be sacred or forbidden (see for example in Laaksonen 1999 and Snowchange Kuivasjärvi Oral History Tape 161013). They are only to be discussed on the lake, in person, and are not to be recorded or written down. 
Secondly, both oral and optic histories from the early 1900s confirm that Lake Kuivasjärvi used to have an endemic population of pikeperch (Sander lucioperca). This is significant because, as eutrophication proceeds and water quality worsens, pikeperch is one of the species which benefits. Additionally, it is the central species in the stocking plans and actions by the local fisheries body, but with stocks introduced from another watershed (Snowchange Kuivasjärvi Oral History Tape 151013). Therefore the genetic pool of the endemic pikeperch mixes most likely with the stocked fish and changes the balance of the lake and fisheries in favour of harvesting the introduced fish.

Finally, the role of common bream (Abramis brama) manifests in the local knowledge and endemic time-spaces of Lake Kuivasjärvi area prominently as an ecological indicator species. It has a central role in the traditional calendar of the community. Three spawning times, which simultaneously refer to the fish themselves (Thrift \& May 2001), kirsilahna ("When the ground is still frozen at night time, mid-May"bream), juhannuslahna ("Mid-summer- bream") and tähkälahna ("When the ear of a grain-bearing tip part of a cereal plant, such as wheat, is visible and ripe-bream") indicate the sizes of fish to be harvested, the smallest first and the largest ones last (Suomen luonto 2007). Documented interviews position the arrival of the common bream to coincide with the large-scale industrial peat production by the state energy company VAPO (Snowchange Kuivasjärvi Oral History Tape 151013).

More precisely, as one fisherman born in the 1930s said:

"At first we did not have common bream on Lake Kuivasjärvi at all. It arrived from lakes Ylinen and Vatajanjärvi, which are upstream from here, when the peat production began to impact those waters. Then the breams swam here, preceding the discharges of peat. We have an old saying regarding the bream in Lake Kuivasjärvi: There was a child of a Roma, living on Lake Kuivasjärvi. He swallowed a bream's fish bone, but it got caught in his throat. The older Roma cursed the common bream because of this and banished them from Lake Kuivasjärvi. All of them then swam downstream, to Lake Linnanjärvi and there were no more breams in Lake Kuivasjärvi after that." (Snowchange Kuivasjärvi Oral History Tape 151013)
Cortazzi (2001) frames the narrative analysis to yield good results in oral history research. In this account, the Roma (Pulma 2012), or the gypsies, play a central role as in many other village stories in the rural Finland. They refer sometimes to the 'other' and do not need to specifically be related to the real-life ethnic Roma. However, as Husso and Raento (2002b) indicate the Roma(ni) have been at "the bottom of the social pecking order" in Finland ever since arriving in 1500s (Rekola 2012) and are consequently a popular subject of oral histories in rural areas (Pulma 2012; Rekola 2012: 67-69).

The endemic time-spaces contain oral histories with a very clear view of the absence of common bream from Lake Kuivasjärvi. Yet, once industrial peat production began, common bream reappeared and remained, as if from the mythological times of the story. Written sources, such as YläSatakunta (1964), from these times identify that within the district of the Kuivasjärvi fishing 'council' (kalastuskunta), between 1954-1964, there were 1,050,000 whitefishs, 250,000 pike perchs, 50,000 vendaces, 700 trouts and 20,000 common breams stocked to various water bodies within its jurisdiction. However, specific reference is made that common bream was not stocked in Lake Kuivasjärvi (see also Aamulehti 1957). Fishermen born in the 1940s and 1950s confirm its reappearance in the 1970s (Snowchange Kuivasjärvi Oral History Tape 110214). Indeed, common bream is another species that benefits from warmer waters and further contributes to eutrophication (Tikkanen 2002b) and other impacts caused by the industrial activities in the watershed.

To summarize, there are living oral histories and practices in the documented endemic timespaces of the Kokemäenjoki River catchment area. They reached their prime prior to largescale industrial uses of the waterways, but currently persist in memory and somewhat in practice. Most importantly, the summer seining along Lake Näsijärvi illustrates the richness of these Western Finnish cultural readings. Secondly, the oral histories as a part of a watershed restoration activities (Mustonen 2013b; Ylä-Satakunta 2013), carry meaning, customary water uses, beliefs, and environmental observations of heavily-damaged areas and key markers of what, where, and how things changed. 


\section{Case of Lake Puruvesi winter seiners in the Vuoksi watershed}

The Vuoksi River catchment area is a major Eastern Finnish watershed, with a total territory of over 52,400 km². The catchment area has territories in North and South Karelia as well as North and South Savo, and consists of several human settlements along its various water bodies. Like the Kokemäenjoki River area, it suffers from various industrial impacts, including hydropower regulation, agriculture, forestry, pulp production, and mining activities, as well as peat production (Maaranen 2002; Tikkanen 2002a, 2002b; Ministry of Environment 2014).

The Vuoksi River catchment area is located in the cultural zones of the Savo-Karelian peoples. Aikio $(2007,2012)$ indicates that many of the place names in the watershed derive from Sámi times and occupancy. The Finnish endemic, surviving time-spaces of Saimaa, the major lake system of Vuoksi, differ from the details and context of Western Finland. An important practice that maintains the living endemic time-spaces of this catchment area is winter seining (Pennanen 1979, 1986) on Lake Puruvesi, which is divided between the North Karelia and South Savo regions.

Here I will focus on the winter seiners of North Karelia. Pennanen (1976) reviewed aspects of communal summer seining on Lake Puruvesi. I have been a part-time member of one of the winter seining crews from 2005-2014 (Mustonen 2014a), which offers a partial-insider view and observational method to the way the endemic time-spaces manifest as a part of this fishery.

Winter fishing has been a crucial subsistence practice in the Eastern Finnish cultural area. The oldest archaeological net finding in the world is from Karelia. One of the most prominent singers of traditional Finnish songs, Juhana Kainulainen, lived in the Lake Puruvesi region in the early 1800s. Kainulainen was a seiner, hunter, tietäjä (spiritual person), and healer. Tietäjä people are still remembered in Kesälahti (Mustonen 2009: 174, 2014a). According to local people, they had the "power of nature flowing through them" (Mustonen 2009: 174).

The nature of North Karelia is primarily middlesouthern boreal taiga ecosystems with large lakes. It is a part of the Eurasian taiga zone, with a shift in climate towards more continental in the eastern parts of the province. The ecosystems have wit- nessed massive human-induced damages in the past 60 years (Tikkanen 2002b for national changes in aquatic ecosystems, Mustonen 2009, 2013a). After the Second World War Finland had to pay war damages to the Soviet Union, which also meant rapid industrial revolution in North Karelia. Most of the old-growth forests were clear-cut and marshlands were transformed into peat production (Mustonen 2009, 2013a). Waterways, such as the Pielisjoki River, home of the fresh-water salmon (Salmo salar) and a relic of the Ice Age, were harnessed for electricity production (Tikkanen 2002a) (Fig. 4). Farming shifted to chemical-driven mass production and runoff from the pulp industries polluted the waters. Mines, including a uranium mine, potentially threaten the already damaged ecosystems. The only existing uranium mine in Finnish history operated in the Pielinen watershed between 1959-1962, producing 30 tonnes of ore (Mustonen \& Mustonen 2013b).

The endemic time-spaces in Eastern Finnish communities are a matrix of discontinued and surviving processes. Two such losses are the traditional songs and the disruption of the endemic cosmology of North Karelia (Mustonen 2009; see also Heikkilä \& Fondahl 2010). The erosion of endemic knowledge (Meriläinen-Hyvärinen 2008) may produce landscapes, which are 'empty', ready for industrial use, nature protection or other

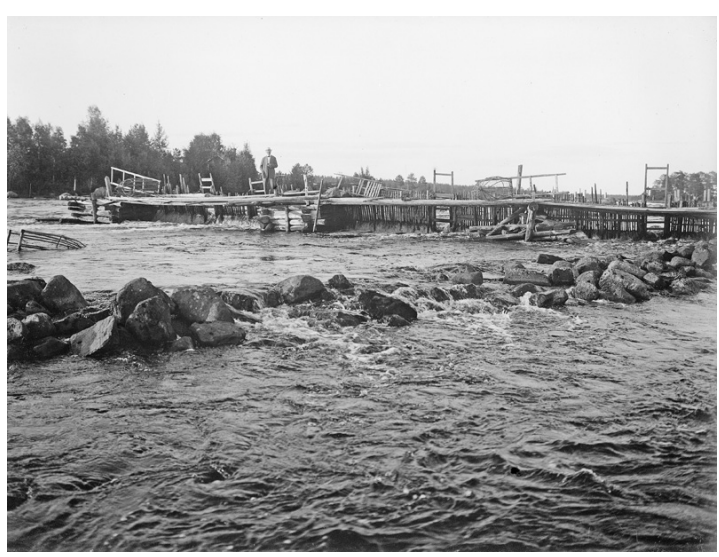

Fig. 4. The fresh water salmon was harvested using traditional fish traps along the spawning river of Pielisjoki, which is today wrecked by several hydroelectric stations. Photo by Finland's National Board of Antiquities 2014. 
modern plans. Those communities, such as the winter seiners of Lake Puruvesi, who still retain the fragments of oral histories and relationships with the multidimensional reality of the lake (Mustonen 2009: 189, 2014a), see their lake as story-filled time-spaces full of significance and meaning.

The local fishing communities in Lake Puruvesi are in a process of latent conflict (Lehtinen 2000; Rytteri 2002; Mustonen 2012, 2013a, 2014b) with these top-down resource extraction plans. What makes this latent state of conflict very complex is that several local people have had to start working in the extractive industries to be able to stay in the region or maintain economic income for their families through small-scale clear-cutting forestry, for example (Mustonen 2014a). Hence, the winter seiners represent a rare pocket of surviving, ongoing community, which is still rooted on the unbroken link with the region's past. But the events and the oral culture on the lake are not a museum piece - rather the fishermen strongly argue that their work, knowledge, and practice is for these times (Mustonen 2014a).

Seine fishing is a cold-based activity in Kesälahti today. It requires proper lake ice and winter conditions to succeed. The season is usually from November to the end of April even though climate change is now changing this (for the northern part of the Eurasian climate, see Arctic Council 2005; Mustonen 2009, 2014a).

The winter seiners have collaborated on an oral history and water-use mapping project since 2005. The topics of the oral history interviews regarding these endemic time-spaces have included land use and fishing area histories, seine fishing styles, locations, the construction of the seine parts and equipment, changes to the community, the role of women in fishing from the early 19th century on, preservation and loss of traditional knowledge regarding weather, ice, snow and fishing, relationships with scientists and authorities, the prediction of weather and weather changes, the effects of the moon on weather, wildlife observations, dream knowledge and spiritual relationships, boat construction, hopes for the future and youth, and border with Russia. Mustonen (2009) summarizes the findings of these oral histories.

Net fishing, especially under-ice winter fishing has been the defining survival method of Arctic and circumpolar societies since the last ice age (Pennanen 1979, 1986; Mustonen 2009). The knowledge complex surrounding the interactions and relationships with the local lakes where this practice continues is significant, deep and requires much consideration to be appreciated.

The place names, hydronyms (Heikkilä \& Fondahl 2010), and oral histories, which have been documented in the region (Pennanen 1979, 1986; Mustonen 2009: 138-192), indicate that the communal seining has been going on since prehistoric times. More specifically, place names such as $\mathrm{PO}_{\mathrm{O}}$ roniemi (Reindeer cape) and Kotaniemi (Cape of Sámi shelters or tipis) (Mustonen 2009: 153) refer to seasonal uses of the lake by the Sámi. Pennanen (1979: 50-51) indicates the apaja hydronyms, such as Talvihauta (Winter deep/grave) to refer to pre- and early historic Karelian seasonal presence in the seining on Puruvesi, prior to 1323, when the written records of harvests began.

During earlier times, seining focused on the coastal zone of the lakes, with the harvest focused on pike and other larger fish at this time. Starting in the early to mid-1900s the catch has been whitefish (Coregonus lavaretus) and vendace (Coregonus albula), which reside in the deep parts of the lake (Pennanen 1979, 1986). All of this harvest was for subsistence use, for food for local communities and households up until the 1800s. Since the early $20^{\text {th }}$ century, the fish has also had a place in urban markets.

The living seiners remember a time in the 1950s when seines were pulled with horses on the ice; no machines were used (Mustonen 2009). Dozens of crews were on the ice harvesting vendace. Poles measuring $42 \mathrm{~m}$ were used to guide the seines under the ice. Customary rights (Raussi 1966; Käki 1969) were respected in terms of the different harvesting locations that each crew accessed. Systems of rotation and traditional ownership were and, to a certain extent, still are practised (Mustonen 2009: 192-196).

The system of apaja sites, much like for the summer seining in Western Finland (Nieminen \& Mustonen 2004), is a word that refers to the place of harvest, the catch place. They have to be known precisely in order for the seining to be successful. Today's nets are 300-320 m x 11-14 m and the lake area is divided into hundreds of apaja sites (Pennanen 1979; Mustonen 2009). Certain sites yield results only under specific natural conditions, some only once a season, others weekly. The fisherman has to know, among other things, the weather conditions, geographical location on the ice, the shapes of the underside of the ice in that location, currents, water depth, and the formations 
of the lake bottom for the pull to succeed. It means that for each apaja site at least five different 'landscapes' (Mustonen 2009, 2014a) have to be mastered in order for the pull to succeed. A mistake of only a few metres can result in a torn seine net and the loss of thousands of euro. This knowledge of the landscape still survives quite well amongst the fishermen who are on the ice today (Mustonen 2014a).

Contemporary fishermen also believe that these sites are owned; they are the customary properties of certain families and individuals (Raussi 1966; Käki 1969). There are rules of behaviour and conduct on and near them. For example, the ice hole where nets are lifted up has to remain ice-free at all times, dreams can show a specific site to be harvested and certain moon cycles influence which apajas are pulled (Mustonen 2009). It is equally important to remember that not all apajas are the same - they have beings and characteristics, which are very subtle in their details. Esa Rahunen, for example, a contemporary leader of fishermen in Puruvesi, 'owns' 135 apaja sites (Mustonen 2009: 172).

A crucial difference between ongoing, surviving seining culture here and Lake Näsijärvi fishery is that the fishermen who own their sites did not want them to be documented in detail. Rather, to create water use maps, regions used through the seasons on the lake were allowed to be mapped, but not the specific sites themselves (see Fig. 5). This may also reflect a bad experience from the 1970s (Pennanen 1979) when certain apaja sites were mapped in detail, but not in full consultation with the fishermen.

The knowledge regarding fishing has been passed on to the contemporary seiners of Lake Puruvesi from an unbroken traditional cycle of oral, practical knowledge transfer (Pennanen 1979, 1986; Lehtinen \& Mustonen 2013). As Pennanen $(1979,1986)$ demonstrates, the seining itself has undergone various technical changes, including limited motorization in the 1900s. The unbroken practice emerges in a sense that apajas are still 'owned' and known orally as well as practically while the ownership and permit issues have also been defined as a part of the modern demarcations in some parts of the western Puruvesi (Pennanen 1979). Of relevance here is that there remains a customary system of selection, use and occupancy of the apaja sites.

Ecologically, seining removes biomass from the northern lakes and therefore has the potential to address nutrient problems associated with eutrophication (Tikkanen 2002a). Puruvesi is extremely vulnerable, due to its pristine water quality, to euthrophication. It has become a significant problem in the lakes of southern Finland due to the climate warming and phosphorous discharges

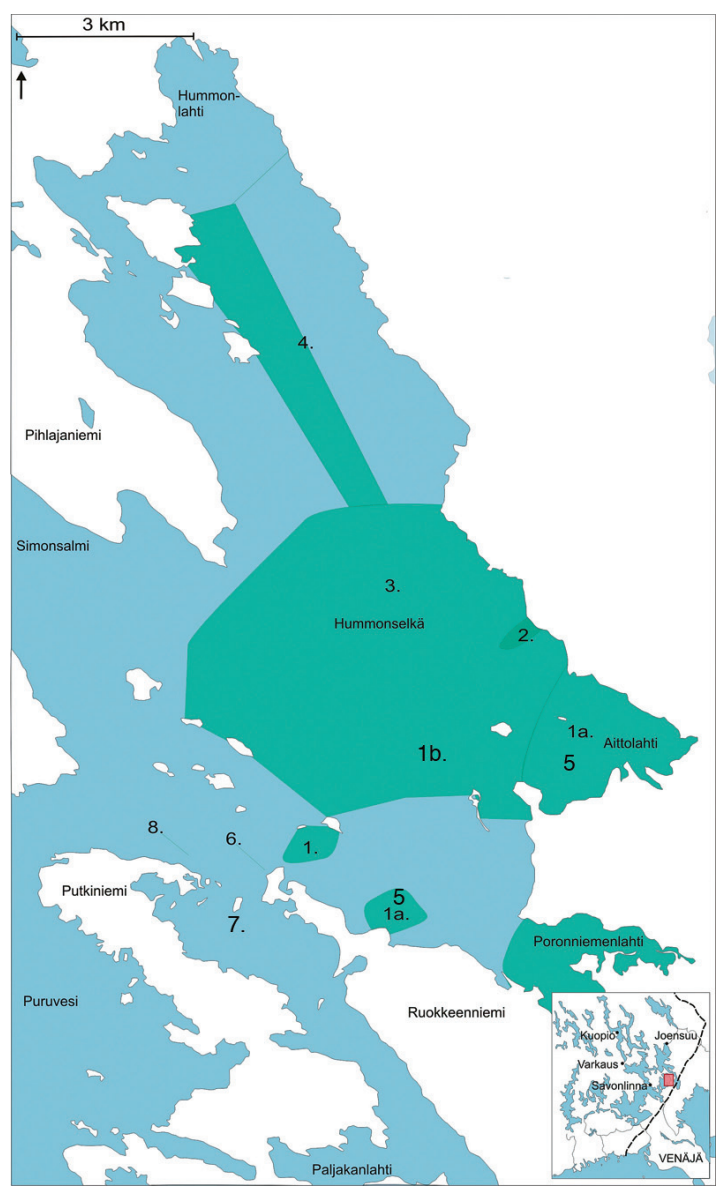

Fig. 5. An example of the water-use occupancy and documentation. The fishing areas of winter seiner Esa Rahunen in the winter 2006-2007. Numbers indicate (adapted from Mustonen 2009): 1. the seining for spawning vendace in the Autumn and early winter apaja sites $1 \mathrm{a}$ and $1 \mathrm{~b} ; 2$. the fish base; 3. the mid-winter apaja areas; 4. the Spring winter apajas from March onwards; 5 . the Spring apaja sites, including again $1 \mathrm{a}$ and $1 \mathrm{~b} ; 6$. the Ohtahauta apaja, a solitary site to be pulled only in the Spring time; 7. the apaja 'Siikasaari', which can be pulled if the ice is thin, and usually gives 200-300 kg of vendace.; 8. Käräjäkallio, a special island in the Lake Puruvesi. 
released by agriculture and washouts from clearcut forests. Seining may help cold-water native species such as white fish and vendace to survive. It removes fish such as roach (Rutilus rutilus) and common bream (Abramis brama) which thrive in warmer waters.

It is equally important to note that this human practice is sustainable only as long as the fishermen know their lakes. Contemporary seiners have fought off trawling on Puruvesi and they have defended their lake against industrial developments (such as water level regulation). This defence rests on the understanding of winter seining as an economic activity in the eyes of the authorities. Its cultural or endemic values have recently been recognized internationally (Umami 2014; Mustonen 2014a). As long as they are on the lake, they will defend the lake. Therefore the seining is crucial for the people, the lake, and the landscape as an endemic time-space (Mustonen 2012, 2014a).

\section{Discussion}

This article has, using carefully selected cases both from Western and Eastern Finland, demonstrated characteristics of concentric geographs (Lehtinen 2010) or endemic time-spaces of Finnish society, communities, and individualities from the 1900s to the early $21^{\text {st }}$ century. Earlier aspects of land use and occupancy mapping in Finland were also partially reviewed, with a special focus on fisheries. Outsiders began mapping these areas already in the 1920s (Pälsi 1924) while more recent efforts have been carried out by the fishermen themselves (Saiha \& Virkkunen 1986; Nieminen \& Mustonen 2004).

A remarkable feature of the knowledge sharing done by Into Sandberg, a professional fisherman on the Finnish coast, is that he chose to do so (Saiha \& Virkkunen 1986) due to the environmental impacts caused by industrial pollution on Baltic herring (Clupea harengus membras). This illustrates the fact that the endemic time-spaces and local knowledge in Finland also contains moral guidance based on a life lived in a close proximity to nature.

The majority of the decisions, zoning and environmental permitting in Finnish catchment areas are built on scientific expert knowledge, linear times and spaces, and rational worldviews (Mustonen 2013a, 2013b). In this time of rapid change (Pretty 2011; Jeffries et al. 2013), a fundamental rethinking is necessary in order to guarantee the survival of local cultures and ecosystems (Lehtinen 2000, 2010, 2011; Lehtinen \& Mustonen 2013). An engagement and respectful work with the people and their endemic time-spaces, such as those presented in these cases, may provide exciting and crucial ways of detecting rapid ecosystem degradation (Mustonen 2013a) or identifying the sites of ecological change (Mustonen \& Feodoroff 2013; Mustonen 2013b).

The practical aspects of including such endemic time-spaces in land use planning, permitting and zoning include the production of user maps (Hudson 2001; Lehtinen 2000). While they are insufficient for portraying the entire range and depth of human agency regarding water bodies, the key aspects of endemic timespaces, fixed on maps, in careful and respectful cooperation with the people possessing them, can offer ways to avoid ecological damage and open doors of emergence to the hidden, deep connections that Finns have with their lakes in this time of change and development.

\section{Conclusions}

The endemicity of Finnish aquatic time-spaces is a process that involves simultaneously radically different meanings. Agricultural-industrial (Maaranen 2002; Tikkanen 2002a, 2002b) development stresses the human actions to alter and shape the water bodies for human needs. Remnants, and in some rare cases, surviving hunting-fishing economies (Sarmela 1991) and associated local knowledge, maintain a lowimpact engagement and a heterogeneity of relationships with the water. Additionally, they display the long cultural continuum, especially in the case of seining inherent in the endemicity of the relationship.

Industrial uses of catchment areas have taken place in Finland for over one-hundred years (Maaranen 2002). At the same time, many ongoing practices along the waterways contain the endemic time-spaces of aquatic regimes. These time-spaces are often hidden or in conflict with demarcated, linear uses of the watersheds (Lehtinen 2000; Mustonen 2013b), which do not illustrate or take into account the local knowledge (Luotonen 2006) inherent in these endemic practices. 
This article has reviewed two major catchment areas and their endemic time-spaces by using cases, mapping, participatory observation, and the employment of oral histories; two in the Western Finland, in the Kokemäenjoki River catchment area, and a third one, Lake Puruvesi in the Vuoksi area. In the Kokemäenjoki area, summer seining on Lake Näsijärvi, a practice that has now been lost, reproduced the intimate, reciprocal relationships that the fishermen had with their lakes. Memories, maps, and photographic, optic histories portray the evidence and manifestations of this endemic aquatic regime.

In the second case, the oral histories of the local fishermen in Lake Kuivasjärvi contain culturally relevant knowledge of traditional beliefs, even old deities, seining place names, impacts of industrial watershed use and ecological change. Three key species of fish, northern pike, pike-perch and common bream, emerge from the oral histories in various capacities as indicators of these themes. Especially the role of common bream could be analysed as a marker of how and to what extent things change on the lake as industries began.

In the Vuoksi system, especially on Lake Puruvesi, professional winter seining maintains a unique, unbroken cultural system of endemic time-spaces. This system manifests at its best through the apaja catch sites, which are localities, times, and customarily owned possessions, some of which date back to the pre- or early historical period. Winter seining also reproduces deeper aspects of the endemic time-spaces, including information about spiritual knowledge and dreams. If these materials are reviewed in all of their diversity, a rich and healthy view of endemic culture along these waters emerges.

\section{ACKNOWLEDGEMENTS}

This article has been enabled by the Turvetuotanto ja vesistövaikutusten hallinta: Relevanteista faktoista tehokkaisiin normeihin / Water Management and Peat Production: From the Relevant Facts to Effective Norms (WAPEAT) (Suomen Akatemian hanke 263465) Project. Thank you to Kaisu Mustonen, Matthew Sawatzky, Pauliina Feodoroff, Ari Lehtinen, Olli Klemola, Esa Rahunen and anonymous reviewers for helpful comments.

\section{REFERENCES}

Aamulehti 1957. Siikaa ja haukea Kuivas- ja Mustajärveen Parkanossa. Newspaper article 30.12.1957 (in Finnish).

Aikio A 2007. The study of Saami substrate toponyms in Finland. In Pitkänen R \& Saarikivi J (eds). Borrowing of place names in the Uralian languages, 159-197. Onomastica Uralica 4. Debrecen, Helsinki.

Aikio A 2012. An essay on Saami ethnolinguistic prehistory. In Grünthal R \& Kallio P (eds). A linguistic map of Prehistoric Northern Europe, 63-118. Suomalaisugrilainen seura, Helsinki.

Antikainen J \& Vartiainen P 2002. Finnish districts and regional differentiation. Fennia 180: 1-2, 183-190.

Arctic Council 2005. Arctic Climate Impact Assessment. $<$ http://www.acia.uaf.edu> 28.1.2014.

Arctic Council 2013. Arctic Biodiversity Assessment. $<$ http://www.arcticbiodiversity.is> 10.9.2014.

Berkes F 1999. Sacred ecology - Traditional ecological knowledge and resource management. Taylor \& Francis, Philadelphia.

Cortazzi M 2001. Narrative analysis in ethnography. In Atkinson P, Coffey A, Delamont S, Lofland J \& Lofland L (eds). Handbook of Ethnography, 384-395. Sage, London. http://dx.doi.org/10.4135/9781848608337.n26.

Great Lakes Indian Fish \& Wildlife Commission 2007. Gidakiiminaan (our Earth): An anishinabe Atlas of the 1836 (Upper Michigan), 1837 and 1842 Treaty Ceded Territories. Great Lakes Indian Fish \& Wildlife Commission, Odanah.

Hudson D 2001. Aboriginal land rights issues, industrialisation and society in British Columbia. In Mustonen T \& Rattray C (eds). Dispatches from the Cold Seas - Indigenous views on selfgovernance, ecology and identity, 15-29. Tampere Polytechnic, Tampere.

Heikkilä K \& Fondahl G 2010. Indigenous toponyms as pedagogical tools: Reflections from research with Tl'azt'en Nation, British Columbia. Fennia 188: 1, 105-122.

Husso K \& Raento P 2002a. Science policy and research in Finland. Fennia 180: 1-2, 261-274.

Husso K \& Raento P 2002b. Cultural diversity in Finland. Fennia 180: 1-2, 151-162.

Hämeen ELY-keskus 2014. Kokemäenjoki. <http:// www.kokemaenjoki.fi/> 28.1.2014 (in Finnish).

Käki M 1969. Kalla - Perämeren kalakari. Otava, Helsinki (in Finnish).

Jeffries M, Overland J \& Perovich D 2013. The Arctic shifts to a new normal. Physics Today 66: 10, 35-40. http://dx.doi.org/10.1063/PT.3.2147.

Laaksonen P 1999. Kotimailla. SKS, Helsinki (in Finnish).

Lehtinen A 2000. Mires as mirrors. Peatlands - Hybrid landscapes of the North. Fennia 178: 1, 125-137.

Lehtinen A 2010. Politics of decoupling: Breaks between indigenous and imported senses of the Nordic North. Journal of Cultural Geography 29: 
1, 105-123. http://dx.doi.org/10.1080/08873631 .2012.655031.

Lehtinen A 2011. From relations to dissociations in spatial thinking: Sámi 'geographs' and the promise of concentric geographies. Fennia 189: 2, 14 30.

Lehtinen A \& Mustonen T 2013. Arctic earthviews: Cyclic passing of knowledge among the indigenous communities of the Eurasian North. Sibirica 12: 1, 39-55(17).

http://dx.doi.org/10.3167/sib.2013.120102.

Luotonen E 2006. Vapaa-ajan kalastajan Oura. In Häyrynen M, Luotonen E, Mustalampi E \& Bruk E (eds). Tuntematon saaristo - Selkämeren saariston eletty maisema, 204-222. Otava, Helsinki (in Finnish).

Maaranen P 2002. Human touch, natural processes: The development of the rural cultural landscape in Southern Finland from past to present. Fennia 180: 1-2, 99-109.

Macdonald J 2000. The Arctic sky - Inuit astronomy, starlore and legend. Royal Ontario Museum, Toronto.

Mazzullo N 2013. The Nellim forest conflict in Finnish Lapland: Between state forest mapping and local forest living. In Miggelbrink J, Habeck JO, Mazzullo N \& Koch P (eds). Nomadic and indigenous spaces: Productions and cognitions, 91-112. Ashgate, Surrey.

Meriläinen-Hyvärinen A 2008. Luonnon kanssa käsikkäin - Selviytymisen strategiat neljässä pohjoissuomalaisessa yhteisössä eri aikoina 1680-luvulta 1900-luvulle. Suomen muinaismuistoyhdistys, Helsinki (in Finnish).

Ministry of Environment 2014. Vuoksen vesienhoitoalue. <http://www.ymparisto.fi/fi-Fl/Vesi_ja_ meri/Vesien_ja_merensuojelu/Vesienhoidon suunnittelu_ja_yhteistyo/Vesienhoitoalueet/ Vuoksi/Vuoksen_vesienhoitoalue(24136> 3.2.2014 (in Finnish).

Mustonen T 2009. Karhun väen ajast-aikojen avartuva avara. University of Joensuu Press, Joensuu (in Finnish).

Mustonen T \& Mustonen K 2011. Eastern Sámi Atlas. Snowchange Cooperative, Kontiolahti.

Mustonen T 2012. Rebirth of indigenous Arctic Nations and polar resource management: critical perspectives from Siberia and Sámi areas of Finland. Biodiversity 14: 1, 18-27.

Mustonen T \& Feodoroff P 2013. Ponoi and Neiden collaborative management plan. Snowchange Cooperative, Kontiolahti.

Mustonen T 2013a. Power discourses of fish death: Case of Linnunsuo peat production. Ambio 43: 2, 234-243. http://dx.doi.org/10.1007/s13280-0130425-3.

Mustonen T 2013b. Oral histories as a baseline of landscape restoration - Co-management and watershed knowledge in Jukajoki River. Fennia 191: 2, 76-91.
Mustonen T 2013c. Kohti saamelaistutkimuksen uutta viitekehystä. In Lehtola V-P, Piela U \& Snellman H (eds). Kalevala-seuran vuosikirja 2012, 254264. SKS, Helsinki (in Finnish).

Mustonen T 2014a. Notes as a member of one of the winter seining crews in Puruvesi 2005-2014.

Mustonen T 2014b. Diary entries from seining activities on Lake Kuivasjärvi 2005-2007. Notes at the possession of the author.

Mustonen T \& Mustonen K 2013a. Jukajoen ja -järven hoitosuunnitelma - Selkien perinteestä ja luonnosta 5. Snowchange Cooperative, Kontiolahti (in Finnish).

Mustonen T \& Mustonen K 2013b. Vaara-Karjalan kulttuuriperintöhanke 2011-2013. Snowchange Cooperative, Kontiolahti (in Finnish).

Mäkinen A \& Mustonen T 2004. Pitkät hylkeenpyyntimatkat ja muita kertomuksia hylkeenpyynnistä. University of Applied Sciences Tampere, Tampere (in Finnish).

Nieminen M \& Mustonen T 2004. Ahdin nuottaapajilla - Pirkanmaan ammattikalastajat. University of Applied Sciences Tampere, Tampere (in Finnish).

Pennanen J 1976. Puruveden kesänuottakalastuksesta. In Turunen A (ed). Kalevala-seuran vuosikirja 56 - Veden viljaa, 106-132. WSOY, Helsinki (in Finnish).

Pennanen J 1979. Muikkuapajilla. Kansatieteen arkisto, Jyväskylä (in Finnish).

Pennanen J 1986. Talviapajilla. Ammattimaisen talvinuottauksen sata vuotta. Suomen kirjallisuuden seuran toimituksia 445. SKS, Helsinki (in Finnish).

Pretty J 2011. Interdisciplinary progress in approaches to address social-ecological and ecocultural systems. Environmental Conservation 38: 2, 127 139. http://dx.doi.org/10.1017/S0376892910000937.

Pulma P 2012 (ed). Suomen romanien historia. SKS, Helsinki (in Finnish).

Pälsi S 1924. Suomenlahden jäiltä. Otava, Helsinki (in Finnish).

Raussi E 1966. Virolahden kansanelämää 1840-luvulla. SKS, Helsinki.

Rekola T 2012. Romanien varhaisvaiheet Suomessa: 1500-luvulta 1800-luvun puoleenväliin. In Pulma $\mathrm{P}$ (ed). Suomen romanien historia, 18-83. SKS, Helsinki (in Finnish).

Rytteri T 2002. Metsäteollisuusyrityksen luonto. Tutkimus Enso-Gutzeitin ympäristö- ja yhteiskuntavastuun muotoutumisesta. University Press, Joensuu (in Finnish).

Saiha M \& Virkkunen J 1986. Kalastaja ilman merta - Into Sandbergin elämää ja kynänjälkeä. WSOY, Porvoo (in Finnish).

Sarmela M 1991. Karhu ihmisen ympäristössä. In Laaksonen P \& Mettomäki S-L (eds). Kolme on kovaa sanaa. Kalevala-seuran vuosikirja 71, 209-250. SKS, Jyväskylä (in Finnish). 
Sheridan J \& Longboat R 2006. The Haudenosaunee imagination and the ecology of the sacred. Space and Culture 9: 4, 365-381. http://dx.doi.org/10.1177/1206331206292503.

Sirelius UT 2009. Suomalaisten kalastus I-III. SKS, Helsinki (in Finnish).

Smith LT 2005. Decolonizing methodologies - Research and indigenous peoples. Zed Books, London.

Suomalaisen Kirjallisuuden Seura 2014. Kansanrunousarkisto. <http://www.finlit.fi/kra/> 3.2.2014 (in Finnish).

Suomela P 1976. Päijänteen siirtolaiskalastajat. In Turunen A (ed). Kalevala-seuran vuosikirja 56 - Veden viljaa, 133-151. WSOY, Helsinki (in Finnish).

Suomen luonto 2007. Lahnojen kutuajat. <http:// www.suomen/uonto.fi/sisalto/artikkelit/13002/> 12.5.2014 (in Finnish).

Syrjämäki E \& Mustonen T 2013 (eds). It is the Sámi who own this land - Sacred landscapes and oral histories of the Jokkmokk Sámi. Snowchange Cooperative, Kontiolahti.

Thrift N \& May J 2001 (eds). Timespace - Geographies of Temporality. Routledge, London.

Tikkanen M 2002a. Long-term changes in lake and river systems in Finland. Fennia 180: 1-2, 31-42.

Tikkanen M 2002b. The changing landforms of Finland. Fennia 180: 1-2, 21-30.

Turunen A 1976. Kalevala-seuran vuosikirja 56 - Veden viljaa. WSOY, Helsinki (in Finnish).

Umami 2014. Puruveden muikku sain EU:n alkuperäistuotemerkinnän. <http://umami.fi/vapaa-aika/jyrki/puruveden-muikku-sai-eun-alkuperaistuotemerkinnan/> 3.2.2014 (in Finnish).

Valonen N 1945. Parkanon ja Kihniön tutkimusretki vuonna 1936. In Satakuntalainen osakunta (ed). Kotiseudullemme II - Julkaisu satakuntalaisen osakunnan 40-vuotisjuhlaan, 26-31. Tyrvään kirjapaino, Vammala (in Finnish).

Vilkuna K 1974. Lohi - Kemijoen ja sen lähialueen lohenkalastuksen historia. Otava, Keuruu (in Finnish).
Virtaranta P 1976. Suomussalmen Kuivajärven kylän kalastuksesta. In Turunen A (ed). Kalevala-seuran vuosikirja 56 - Veden viljaa, 152-180. WSOY, Helsinki (in Finnish).

Ylä-Satakunta 1964. Kymmenen vuotta kalavesien hoitoa ja kalastuksen järkiperäistämistä Kuivasjärvellä. Newspaper article 3.4.1964 (in Finnish).

Ylä-Satakunta 2013. Kuivasjärvi-kansanliike perustetaan pikaisesti. Newspaper article 01.08.2013 (in Finnish).

\section{Oral sources}

The oral history materials used in the article have been digitally recorded, and transcribed into Finnish. These transcripts form the basis of the English quotes used here. All interviewed people have received copies of the tapes and transcripts prior to publication, and have approved their use. They are co-owners of the materials and requested to be quoted anonymously for this article.

a. Group interview with a farmer-fisherman couple, man born 1936 and woman born 1939, Kuivasjärvi, Parkano, tape: Snowchange Kuivasjärvi Oral History Tape 151013

b. 73-year-old farmer-fisherman, Kuivasjärvi, Parkano, file: Snowchange Kuivasjärvi Oral History Tape 161013

c. Group interview with the head of the fishermen (born 1949) and a winter net fisherman (born 1953), Kuivasjärvi, Parkano, tape: Snowchange Kuivasjärvi Oral History Tape 110214

d. 92-year-old man, farmer, subsistence fisherman, Kuivasjärvi, Parkano, tape: Snowchange Kuivasjärvi Oral History Tape 120214

e. Snowchange Ahlgrén Oral History Tapes 2002-2010, tapes with professional seiner and fish administrator Simo Ahlgrén, collected over eight years, who passed away in 2011 at the age of 87 (born 1924). He lived in Tampere. Total amount of tapes 15 hours. 